\title{
SZÉKELYKERESZTÚRI VÁROSI KÖNYVTÁR
}

Székelykeresztúri Városi Könyvtár

Cím: Székelykeresztúr, Szabadság tér 22.

Honlap: online katalógus: http://keresztur.ro/index.php/hu/kultura/varosi-koenyvtar https://www.facebook.com/konyvtarkeresztur/

E-mail:malakka11@yahoo.com

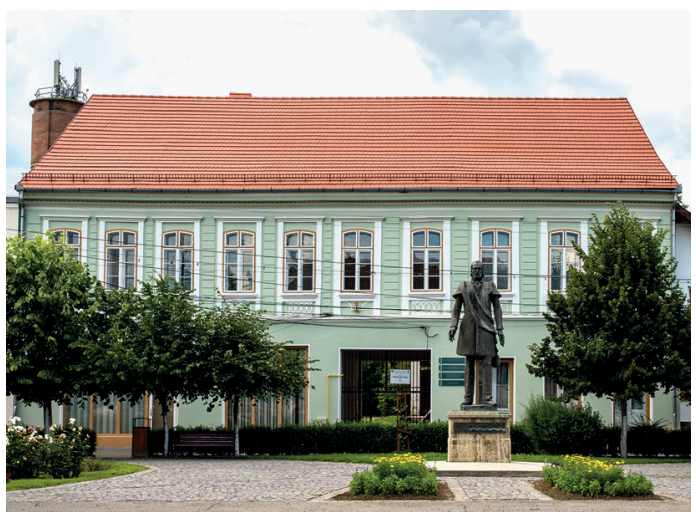

Mint sok más közkönyvtár esetén, a Székelykeresztúri Városi Könyvtár előzményét is egy iskolakönyvtár jelentette. Sándor János A Székelykereszturi Unitárius Gymnasium történelme címú művéből megtudhatjuk, hogy a könyvtár egykorú az iskolával; nagylelkű adományokból és az intézmény pénzén alakult 1798-ban.

A katalógusoknak és egyéb más bizonylatoknak, amelyek a kezdetektől nyilvántartották a könyveket, és átvészelték a két világégést, nyoma veszett a kommunizmus alatt. De az egykori újságokból, monografikus írásokból, nyomtatásban is napvilágot látott könyvekből, elbeszélésekből tudjuk, hogy a város tehetősebb polgári rétege a múltban iskoláknak, egyházaknak adományozott könyveket, megalapozva ezzel a későbbi városi könyvtár állományát.

A 19. század második felében sorra alakultak meg a város művelődési, szakmai és jótékonysági egyesületei. Ilyen volt 1867-ben a Székelykeresztúri Olvasó- és Társaskör, amely aztán pár évvel később, 1894-től, már Kaszinóként is működött. Ezen polgári társaságok mind fontosnak tartották elérhetővé tenni a könyveket bárki számára.

A Székelykeresztúri Városi Könyvtár 1952-ben Falusi Könyvtár néven kezdte meg működését; könyvállományának nagysága ekkor 2081 könyv volt. Míg az 1960-as, 1970-es és 1980as években a Könyvelosztó Vállalat látta el könyvekkel a könyvtárat, 1990 után ez a terület a Városi Tanácshoz tartozott. Napjainkban az állomány több mint 55000 kötetből áll - pályázatokból, a Székelykeresztúr Város

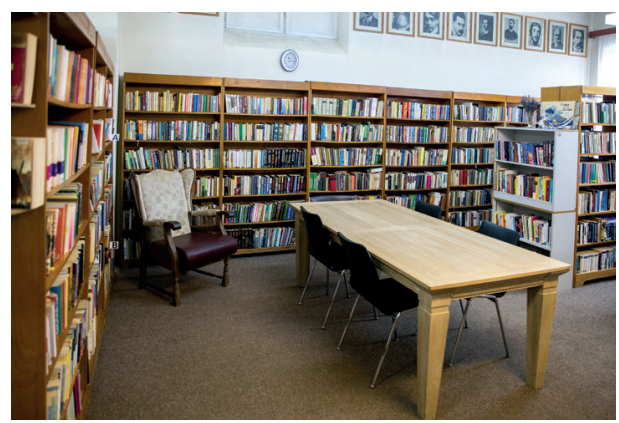






Önkormányzata által kiutalt költségvetésből, valamint civil adományokból növeljük az állományt.

A Városi Könyvtár ma nagy tudás- és dokumentumvagyonnal várja olvasóit. Ezt bővítette az EISZ által biztosított felbecsülhetetlen online szakirodalmi és közművelődési források elérése. Az egyetemisták, a továbbképzéseken résztvevő felnőttek, pedagógusok, érdeklődő olvasók keresik ezeket a munkákat.

Intézményünk óvodákkal, iskolákkal, egyházakkal és kulturális szervezetekkel ápol jó kapcsolatokat. Így közös múvelődési tevékenységek színtere vagy partnere, minden olyan mozzanattal, amelynek a tájékozódás, az olvasási élmény megszerettetése a lényege. Irodalmi és más múvelődési körök koordinátora; kezdeményezője és támogatója múvészeti tevékenységeknek; házigazdája a rendszeresen megtartandó, több évre szóló ifjúsági és felnőtt oktatásnak, más programoknak.

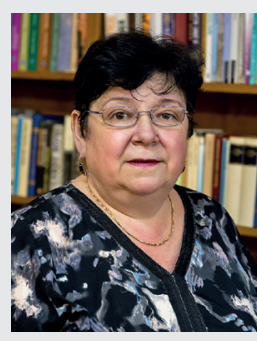

Lőrinczi Edit

Mérnöktanár, könyvtáros. Nevelőként dolgozott egy tehetséggondozó kollégiumban, majd tanárként erdélyi iskolákban. 16 éve dolgozik a Székelykeresztúri Városi Könyvtárban. 